\title{
PROMOTING MEASURES FOR PREVENTING CONFLICTS BETWEEN FARMERS AND CATTLE HERDSMEN IN RURAL COMMUNITIES OF BENUE STATE, NIGERIA
}

\begin{abstract}
MBAH EN ${ }^{1 *}$, AMAH NE ${ }^{2}$, MITU BS $^{3}$
${ }^{1}$ Department of Agricultural Extension and Communication, Federal University of Agriculture, Makurdi, Nigeria. ${ }^{2}$ Department of Agricultural Extension and Management, Federal College of Animal Health and Production Technology, Vom, Plateau State, Nigeria. ${ }^{3}$ Department of Agricultural Economics and Extension, Abubakar Tafawa Balewa University, Bauchi, Nigeria. Email: evanmbah@gmail.com
\end{abstract} Received: 22 January 2021, Revised and Accepted: 19 February 2021

\section{ABSTRACT}

Objective: The study was carried out to identify measures for preventing conflicts between farmers and cattle herdsmen in rural communities of Benue State, Nigeria. The specific objectives were to: Describe the socioeconomic characteristics of the respondents; ascertain the causes of conflict between farmers and cattle herdsmen in the study area; and identify measures required for preventing conflicts between farmers and cattle herdsmen.

Methods: Data were collected from a sample of one hundred and eighteen (118) respondents in four communities in the study area using a wellstructured questionnaire. Descriptive statistics such as frequency, percentage, mean, and standard deviation were used for data analysis.

Results: Majority (90.7\%) of the respondents had farming as a major source of livelihood, 55.1\% were male while $62.7 \%$ were married. Damage to crops by cattle $(\overline{\mathrm{x}}=2.72)$, uncontrolled grazing $(\overline{\mathrm{x}}=2.52)$, herders claiming the land as common property $(\overline{\mathrm{x}}=2.40)$, and destruction of farmland ( $\overline{\mathrm{x}}=2.30)$ were the major causes of conflicts. Measures required for preventing conflicts between farmers and cattle herdsmen include herdsmen education on the effects of the conflict ( $\bar{x}=2.21)$, signing of a peace accord by both parties $(\bar{x}=2.12)$, establishment of ranches $(\bar{x}=2.06)$, implementation of law prohibiting open grazing $(\overline{\mathrm{x}}=2.05)$, and disarming both parties $(\overline{\mathrm{x}}=1.87)$.

Conclusion: Educating farmers and herdsmen on the effects of the conflict, signing of a peace accord agreement by both parties, establishment of ranches, implementation of law prohibiting open grazing, and disarming both parties were measures required for preventing conflicts between farmers and cattle herdsmen. It is recommended that law enforcement agencies should enforce law on open grazing to avoid conflicts between farmers and cattle herdsmen in the area.

Keywords: Measures, Conflicts, Farmers, Cattle herdsmen, Rural communities, Nigeria.

(C) 2021 The Authors. Published by Innovare Academic Sciences Pvt Ltd. This is an open access article under the CC BY license (http://creativecommons. org/licenses/by/4.0/) DOI: http://dx.doi.org/10.22159/ijags.2021v9i2.40878. Journal homepage: https://innovareacademics.in/journals/index.php/ijags

\section{INTRODUCTION}

Agriculture is fundamental to life sustenance and economy of Nigeria, providing employment for $70 \%$ of the population. It provides food for human consumption and raw materials for export and manufacturing industries. The sector is being transformed by commercialization at the small, medium, and large-scale enterprise levels. Some of the major crops produced in Nigeria include soya beans, sesame, cassava, cocoa, beans, groundnuts, gum arabic, maize, melon, and yams. Livestock reared includes sheep, goat, cattle, pig, rabbit, and poultry [1].

According to Adisa and Adekunle [2], destruction of crops by cattle and property such as irrigation equipment and infrastructure by the herdsmen has resulted in conflicts between the two groups of people especially in Nigeria. Adamu stressed that the conflict between these two groups has led to loss of properties worth millions of naira and the death of hundreds of thousands of people. The frequency and scale of these conflicts have become alarming [3].

Farmers and herdsmen conflicts in Nigeria have spread and intensified over the past decade which poses a threat to national survival and integration. Thousands of people have been killed, communities have been destroyed, and so many farmers and herdsmen have lost their lives and property in an extended orgy of killings and destruction that is not only continuously destroying livelihoods but also affecting national cohesion [4].

Conflict resolution between the farmers and herdsmen should be prioritized in line with the roles of traditional rulers, community village heads, and religious leaders who are likely to be more informed on the root causes of the clashes [1]. There should be equitable distribution of power, wealth, status, and responsibilities among all ethnic communities in the country. Equality must be re-installed in our traditional institutions and judiciary system. Individuals must shun undesirable elements that could capitalize on insecurity to attack innocent citizens. Various social traditional institutions in the community should always encourage their members on attitudinal change in their mind sets and proper orientation toward others. This can be achieved through proper education and enlightenment [1].

The role of traditional and community leaders in dispute resolution needs not to be emphasized. The traditional community leaders are products of people's consensus, customs, and cultures. Traditional and community leaders are well respected because they play major role in settling disputes among members of the community. They are also engaged in resolving conflicts between farmers and herdsmen in rural communities of Nigeria where clashes usually occur.

Grassroots community-based activities, good governance, collaborations, negotiation, reconciliation, mediation, arbitration, adjudication, and crisis management are some of the strategies which can be used in resolving crisis between farmers and herdsmen.

The strategies if used properly can significantly reduce conflicts between farmers and herdsmen, enhance pastoralism and bring about economic, ecological, and political stability in not only Nigeria but also in sub-Saharan Africa at large [5]. It has therefore become necessary to carry out this research to answer the following pertinent questions. What are the socioeconomic characteristics of the respondents? What are the causes of conflict between farmers and cattle herders in the 
Innovare Journal Of Agri. Sci, Vol 9, Issue 2, 2021, 5-8

study area? What are the measures required to bring to an end conflicts between farmers and cattle herdsmen?

The specific objectives were to:

i. Describe the socioeconomic characteristics of the respondents;

ii. Ascertain the causes of conflict between farmers and cattle herdsmen in the study area; and

iii. Identify measures required for preventing conflicts between farmers and cattle herdsmen.

\section{METHODS}

The study was carried out in Benue state, Nigeria. The state derived its name from river Benue, the largest river in Nigeria. It was created on February 1976 along with six other states of the federation. It lies between latitude $8-10^{\circ} \mathrm{N}$ and longitude $6-8^{\circ} \mathrm{E}$. It has a land mass of 6.575 million hectares [6]. Benue state has a total population of 4,219,244 (National Population Census [NPC], 2006) which is made up of 413,159 farm families [6].

The state is bounded by Nasarawa State in the north, Taraba State in the east, Cross-River State in the South, Enugu State in the south-west, Ebonyi State in the south central, and Kogi State in the west and in the south east by Cameroon Republic. The state is administratively divided into three zones, namely, Zone A (Eastern Zone), Zone B (Northern Zone), and Zone C (Central Zone) and has 23 local government areas. There are three prominent ethnic groups in the state, namely, Tiv, Idoma, and Igede. Other smaller ethnic groups are Etulo, Abakpa, and Jukun. Even though there are variations in norms, language, and festivals, the entire population is predominantly farmers. The predominant occupation of inhabitants of Benue State is farming with over $80 \%$ engaged in the occupation and highly noted for substantial cultivation of arable crops such as yam, cassava, rice, soybean, maize, and other staples. Livestock especially small ruminants are reared extensively in this area.

The population for the study comprised farmers in Benue State, Nigeria. Zone B was selected for this study out of the three zones using simple random sampling technique. Second, two local government areas, namely, Guma and Gwer West were selected out of eight local government areas in the Zone because of the frequent occurrence of farmers and cattle herdsmen conflict in the area. Two communities were selected randomly from each of the local government areas which gave a total of four communities. In each of the communities selected, 30 heads of households were selected for the study, totaling a sample size of 120 respondents.

Data for the study were collected from primary source using interview schedule/questionnaire. Interview schedule was used for illiterate farmers while questionnaire was used for literate farmers. Two copies of questionnaire were not returned, leaving a total of 118 copies of questionnaire used for the study. Data for this study were analyzed using descriptive statistics such as frequency, percentage, mean score, and standard deviation.

\section{RESULTS AND DISCUSSION}

\section{Socioeconomic characteristics of the respondents}

Sex

Results in Table 1 showed that $55.1 \%$ of the respondents were male while $44.9 \%$ of them were female. This implies that male farmers were mostly heads of their households in the study area. This conforms to the findings of Ochokwunu [7] who reported that male dominating occupations are more rampant than the female kind of occupation especially tedious occupation like farming.

\section{Age (years)}

The age distribution of the respondents showed that $50 \%$ were aged 26-35 years and $12.7 \%$ were between the age of 15 and 25 years, among others (Table 1 ). The mean age was 38 years. This shows that majority of the respondents were middle-aged and in their productive years. It is interesting to note that middle-aged farmers are more motivated, innovative, and adaptable which is a good prospect for agriculture.
Table 1: Distribution of respondents according to socioeconomic characteristics $(n=118)$

\begin{tabular}{|c|c|c|c|}
\hline $\begin{array}{l}\text { Socioeconomic } \\
\text { characteristics }\end{array}$ & Frequency & Percentage & $\begin{array}{l}\text { Mean } \\
\text { score }\end{array}$ \\
\hline \multicolumn{4}{|l|}{ Sex } \\
\hline Male & 65 & 55.1 & \\
\hline Female & 53 & 44.9 & \\
\hline \multicolumn{4}{|l|}{ Age (years) } \\
\hline $15-25$ & 15 & 12.7 & \\
\hline $26-35$ & 59 & 50.0 & \\
\hline $36-45$ & 34 & 28.8 & 38.01 \\
\hline Above 45 & 10 & 8.5 & \\
\hline \multicolumn{4}{|l|}{ Marital status } \\
\hline Single & 25 & 21.2 & \\
\hline Married & 74 & 62.7 & \\
\hline Widowed & 13 & 11.0 & \\
\hline Divorced & 3 & 2.5 & \\
\hline Widower & 3 & 2.5 & \\
\hline \multicolumn{4}{|l|}{$\begin{array}{l}\text { Number of years } \\
\text { spent in school }\end{array}$} \\
\hline None & 37 & 31.4 & \\
\hline $1-5$ & 43 & 36.4 & 10.1 \\
\hline $6-10$ & 8 & 6.8 & \\
\hline $11-15$ & 25 & 21.2 & \\
\hline Above 15 & 5 & 4.2 & \\
\hline \multicolumn{4}{|l|}{$\begin{array}{l}\text { Household } \\
\text { size (numbers) }\end{array}$} \\
\hline $1-3$ & 8 & 6.8 & \\
\hline $4-6$ & 27 & 22.9 & 7.17 \\
\hline $7-9$ & 49 & 41.5 & \\
\hline Above 9 & 34 & 28.8 & \\
\hline \multicolumn{4}{|l|}{ Major occupation } \\
\hline Trading & 3 & 2.5 & \\
\hline Farming & 107 & 90.7 & \\
\hline Teaching & 3 & 2.5 & \\
\hline Artisan & 3 & 2.5 & \\
\hline \multicolumn{4}{|l|}{ Farm size (hectares) } \\
\hline $1-5$ & 18 & 15.3 & \\
\hline $6-10$ & 34 & 28.8 & 5.57 \\
\hline Above 10 & 62 & 52.5 & \\
\hline \multicolumn{4}{|l|}{ Farming } \\
\hline \multicolumn{4}{|l|}{ experience (years) } \\
\hline $1-5$ & 4 & 3.4 & \\
\hline $6-10$ & 16 & 13.6 & 23.25 \\
\hline Above 10 & 96 & 81.4 & \\
\hline \multicolumn{4}{|l|}{ Annual } \\
\hline \multicolumn{4}{|l|}{ income (Naira) } \\
\hline$<100,000$ & 8 & 6.8 & \\
\hline $100,000-300,000$ & 40 & 33.9 & 163098.64 \\
\hline $300,001-500,000$ & 40 & 33.9 & \\
\hline 500,001 and above & 30 & 25.4 & \\
\hline \multicolumn{4}{|l|}{$\begin{array}{l}\text { Land ownership } \\
\text { system }\end{array}$} \\
\hline Inheritance & 88 & 74.6 & \\
\hline Communal & 23 & 19.5 & \\
\hline Lease & 5 & 4.2 & \\
\hline
\end{tabular}

\section{Marital status}

Results in Table 1 also showed that $62.7 \%$ were married, $21.2 \%$ of the respondents were single, $11 \%$ were widowed, and $2.5 \%$ were divorced while $2.5 \%$ were widower: This indicates that the majority of the people were married. This is understandable because of needed labor in the farm among other responsibilities. This conforms to the finding of Ochokwunu [7] which stated that majority of the farmers in the rural areas were married.

\section{Number of years spent in school}

About $36 \%$ of the respondents spent $1-5$ years in school, $31.4 \%$ of the respondents did not go to school at all, and $21.2 \%$ of them spent 11-15 years in school while $6.8 \%$ spent $6-10$ years, among others 
(Table 1). This indicates that most of the respondents were educated. This collaborates with a study carried out by Adebayo and Olaniyi [8] who stated that education is another factor which could lead to conflict because education enlightens people about their rights and they have access to information as regards their existence and treating them as inferior could lead to conflict.

\section{Household size}

About $42 \%$ of the respondents have household size of between 7 and 10 people. The mean household size was 7 persons (Table 1). This implies that the respondents have considerable large family size. This finding is supported by the a study done by Akujiobi et al. [9] which noted that most crop farmers believed that it is better to have more children who would work on the farm than hiring external labor. The polygamous nature of the community which allows a man to marry more than one woman could be another reason why they have more children.

\section{Major occupation}

Majority $90.7 \%$ of the respondents were farmers while $2.5 \%$ were engaged in trade, teaching, artisan, and among other type of occupation (Table 1). This is clear that majority of the people were farmers in the area. This conforms to the assertion of Achetu [10] which stated that majority of the rural dwellers are farmers.

\section{Farm size (hectares)}

Entries in Table 1 showed that a greater percentage (52.5\%) of the respondents have farm size of 11 hectares and above. The mean farm size was 5.57 hectares. This implies that the respondents were mostly subsistence farmers. This corroborates to the finding of Aliyu [11] which indicated that low farm size may be due to high pressure on land as a result of increase in population vis-à-vis the traditional land tenure of inheritance, whereby the land is usually divided into pieces and shared among several family members. The implication is an increase in the tendency of the farmers to encroach more land reserves and cattle tracts, thereby creating room for conflict.

\section{Farming experience (years)}

Majority $(81.4 \%)$ of the respondents had farming experience of 11 years and above, $13.6 \%$ had farming experience of between 6 and 10 years while $3.4 \%$ had farming experience of between 1 and 5 years (Table 1). The mean farming experience was 23.25 years. This implies that most of the farmers have been farming for a long period of time. It could be understood that majority were born into farming and they continued in the occupation.

\section{Annual income (Naira)}

Results in Table 1 showed that 33.9\% of the respondents obtained between $\$ 100,000$ and $\$ 500,000$ in a year, $25.4 \%$ got $\$ 500,001$ and above, about $6.8 \%$ of the respondents obtained less than $\$ 100,000.00$. The mean annual income was $\$ 163,098.64$. This implies that farmers in the study area are subsistence farmers and lack the necessary resources to produce for a commercial purpose.

\section{Land ownership system}

A greater percentage (74.6\%) of the respondents acquired their lands for farming through inheritance, $19.5 \%$ acquired theirs as community property while $4.2 \%$ had theirs by lease. The implication of the inherited land means that most of the respondents are indigenes of the study area and such places are their ancestral homes and will resist any opposition that comes against it. This is in agreement with Tenuche and Ifatimehin [12] who pointed out in their separate studies that land in most communities in Nigeria especially among the Tiv people in the Benue valley is freighted with symbolic meaning. It is sacred and considered as an ancestral and historical sphere of influence. Considering this, conflicts over land are usually fierce with massive destruction of lives and properties.

\section{Causes of conflict between farmers and cattle herdsmen}

Table 2 showed the causes of conflict between farmers and cattle herdsmen which include damage to crops by cattle $(\bar{x}=2.72)$,
Table 2: Mean score of causes of conflict between farmers and cattle herdsmen

\begin{tabular}{|c|c|c|}
\hline Causes of conflict & $\begin{array}{l}\text { Mean } \\
\text { score }\end{array}$ & $\begin{array}{l}\text { Standard } \\
\text { deviation }\end{array}$ \\
\hline Damage to crops by cattle & 2.72 & 0.52 \\
\hline Sexual harassment of women and girls & 2.14 & 0.91 \\
\hline $\begin{array}{l}\text { Pollution of stream water in the } \\
\text { community }\end{array}$ & 2.34 & 0.81 \\
\hline Uncontrolled grazing of cattle & 2.52 & 0.73 \\
\hline Cultural difference & 1.74 & 1.07 \\
\hline Language barrier & 1.78 & 1.05 \\
\hline $\begin{array}{l}\text { Non-compliance to traditional grazing } \\
\text { custom }\end{array}$ & 1.62 & 1.11 \\
\hline Destruction of farmland by cattle & 2.34 & 0.83 \\
\hline $\begin{array}{l}\text { Unaccepted grazing of herders on farm } \\
\text { land without permission }\end{array}$ & 2.19 & 0.88 \\
\hline Non-compliance with laid down rules & 1.99 & 1.02 \\
\hline Pilferage from the farmers farms & 1.91 & 0.91 \\
\hline $\begin{array}{l}\text { Herders giving grazing right by } \\
\text { community heads without the consent of } \\
\text { the farmers in the area }\end{array}$ & 2.13 & 0.89 \\
\hline $\begin{array}{l}\text { Destruction of irrigation equipment by } \\
\text { herders }\end{array}$ & 2.04 & 1.02 \\
\hline Burning of rangeland & 2.34 & 0.85 \\
\hline $\begin{array}{l}\text { Herders claiming the land as common } \\
\text { property }\end{array}$ & 2.40 & 0.75 \\
\hline Damage to ecosystem & 2.01 & 1.03 \\
\hline Rustling of cattle & 2.07 & 1.01 \\
\hline
\end{tabular}

uncontrolled grazing $(\bar{x}=2.51)$, herders claiming the land as common property $(\bar{x}=2.40)$, pollution of stream water in the community by cattle $(\overline{\mathrm{x}}=2.34)$, destruction of farmland $(\overline{\mathrm{x}}=2.34)$, burning of rangeland $(\bar{x}=2.34)$, unacceptable grazing of farmland without permission $(\bar{x}=2.19)$, sexual harassment of women and girls $(\bar{x}=2.14)$, herders giving grazing right by community heads without the consent of the farmers in the area $(\bar{x}=2.12)$, rustling of cattle $(\bar{x}=2.07)$, destruction of irrigation equipment by herdsmen $(\bar{x}=2.04)$, damage to ecosystem $(\bar{x}=2.01)$, non-compliance with laid down rules $(\bar{x}=1.99)$, pilferage from the farmers' farms $(\bar{x}=1.91)$, language barrier $(\bar{x}=1.78)$, cultural difference $(\bar{x}=1.74)$, and non-compliance to traditional grazing custom ( $\overline{\mathrm{x}}=1.62)$. The standard deviation indicated the disparities on the responses of the respondents having a standard deviation of more than 1 .

The findings of this study agree with Okoli and Atelhe [13] who observed that unauthorized encroachment into farmlands have led to serious conflicts between the farmers and herdsmen in recent times because of the damage they cause to crops and fallow lands left to replenish the nutrients after long years of use. The findings of this study also conform to the assertion of Aliyu [14] who reiterated that the attitude of the herdsmen on foreign land encroachment in no doubt provokes farmers to unneeded responses.

Measures required for preventing conflicts between farmers and cattle herdsmen

Findings in Table 3 indicated measures for preventing conflicts between farmers and cattle herdsmen which include herdsmen education on the effects of the conflict ( $\bar{x}=2.21$ ), signing of a peace accord by both parties $(\bar{x}=2.12)$, farmers education on the effects of the conflict $(\bar{x}=2.11)$, establishment of ranches $(\bar{x}=2.06)$, implementation of law prohibiting open grazing $(\bar{x}=2.05)$, establishment of grazing reserves $(\bar{x}=1.95)$, use of traditional leaders as mediators $(\bar{x}=1.90)$, equitable distribution of power $(\overline{\mathrm{x}}=1.90)$, disarming both parties $(\overline{\mathrm{x}}=1.87)$, amicable resolution $(\overline{\mathrm{x}}=1.86)$, control and regulation of possession of arms and ammunition $(\bar{x}=1.84)$, equitable distribution of wealth $(\bar{x}=1.71)$, establishment of free toll call and distress centers ( $\bar{x}=1.62)$, allocation of land to nonindigenes $(\bar{x}=1.51)$, verbal warning to herdsmen on areas to graze $(\bar{x}=1.47)$, and payment of compensation by herdsmen to farmers $(\overline{\mathrm{x}}=1.45)$. The standard deviation was more than 1 which indicates 
Table 3: Mean scores of measures required for preventing conflicts between farmers and cattle herdsmen

\begin{tabular}{|c|c|c|}
\hline Measures & $\begin{array}{l}\text { Mean } \\
\text { score }\end{array}$ & $\begin{array}{l}\text { Standard } \\
\text { deviation }\end{array}$ \\
\hline $\begin{array}{l}\text { Payment of compensation by } \\
\text { herdsmen to farmers }\end{array}$ & 1.45 & 1.27 \\
\hline $\begin{array}{l}\text { Verbal warning to herdsmen on areas } \\
\text { to graze }\end{array}$ & 1.47 & 1.34 \\
\hline Amicable resolution & 1.86 & 1.04 \\
\hline $\begin{array}{l}\text { Implementation of law prohibiting } \\
\text { open grazing }\end{array}$ & 2.05 & 1.00 \\
\hline Establishment of ranches & 2.06 & 0.95 \\
\hline Establishment of grazing reserves & 1.95 & 0.94 \\
\hline $\begin{array}{l}\text { Farmers education on the effects of the } \\
\text { conflict }\end{array}$ & 2.11 & 0.80 \\
\hline $\begin{array}{l}\text { Herdsmen education on the effects of } \\
\text { the conflict }\end{array}$ & 2.21 & 0.81 \\
\hline $\begin{array}{l}\text { Signing of a peace accord by both } \\
\text { parties }\end{array}$ & 2.12 & 0.82 \\
\hline Disarming both parties & 1.87 & 0.98 \\
\hline $\begin{array}{l}\text { Establishment of free toll call and } \\
\text { distress centres }\end{array}$ & 1.62 & 1.03 \\
\hline $\begin{array}{l}\text { Control and regulation of arms } \\
\text { ammunition posses }\end{array}$ & 1.84 & 1.03 \\
\hline Use of traditional leaders as mediators & 1.90 & 0.95 \\
\hline Equitable distribution of power & 1.90 & 0.99 \\
\hline Allocation of land to non-indigenes & 1.51 & 1.09 \\
\hline $\begin{array}{l}\text { Equitable distribution of wealth and } \\
\text { responsibility }\end{array}$ & 1.71 & 1.04 \\
\hline
\end{tabular}

the disparities on the responses of the respondents. This finding also conforms to the study carried out by Abbass [15] which emphasized that the better way to keep check of farmers and cattle herdsmen conflicts is to constitute community security outfit for amicable resolution and law enforcement. The authors also reiterated the importance of law prohibiting open grazing and establishment of grazing reserves.

\section{CONCLUSION}

A greater percentage of the respondents were male, married, and had farming as a major source of livelihood. Major causes of farmers and cattle herdsmen conflicts were damage to crops by cattle, uncontrolled grazing, herders claiming the land as common property, and destruction of farmland. Educating herdsmen on the effects of the conflict, signing of a peace accord agreement by both parties, establishment of ranches, implementation of law prohibiting open grazing, and disarming both parties were measures required for preventing conflicts between farmers and cattle herdsmen. The study recommends that farmers and herdsmen should adhere strictly to lay down rules to avoid conflicts between the two groups. It also emphasized the need for law enforcement agencies to ensure that anti-open grazing law is obeyed to avoid conflicts between farmers and cattle herdsmen in the area.

\section{REFERENCES}

1. Abubakar MB. Sociological Assessment of Nomadic Pastoralist and Sedentary Farmers Conflicts in Katsina State. M.Sc., Thesis Submitted to Department of Sociology, Ahmadu Bello University, Zaria; 2015.

2. Adisa SR, Adekunle OA. Farmer herdsmen conflicts: A factor analysis of socio-economic conflict variables among arable crop farmers in North Central, Nigeria. J Hum Ecol 2010;30:1-9.

3. Adamu MM. Colonial origins of post-colonial conflicts between cattle rearers and farmers in Katsina State. In: Olayemi A, Fwatshek SU, Okpeh OO, editors. Historical Perspectives in Nigeria's Post-Colonial Conflicts. Nigeria: Unimark Limited; 2007.

4. Gyong J. The Structure of Communication in Peace and Conflict Resolution, Identity, Crisis and Development in Africa. Nigeria: Malt house Lagos; 2007. p. 120-32.

5. Higazi A. Farmer-pastoralist conflicts in Jos Plateau, Central Nigeria: Security responses of local vigilantes and the Nigerian State. Confl Sec Dev 2016;16:365-85.

6. Benue State Agricultural and Rural Development Authority. Highlights of BNARDA Programmes, Makurdi; 1999. p. 1-15.

7. Ochokwunu BE. Factors Limiting the use of Information and Communication Technologies among Yam Farmers in Benue State, Nigeria. Department of Agricultural Extension and Communication, Federal University of Agriculture, Makurdi; 2015. p. 24-5.

8. Adebayo O, Olaniyi A. Factors associated with pastoral and crop farmers conflict in dried Savannah Zone of Oyo state Nigeria. J Hum Ecol 2008;23:71-4.

9. Akujiobi CT. Arable land resource conflict in Nigeria. Appl Dev Sci 2017;72:39-65.

10. Achetu JA. Bringing Stakeholders into Agricultural Extension Reform Agenda: A Participatory SWOT Analysis of the Trinidad National Agricultural Extension Services. AIAEE 22 nd Annual Conference Proceedings; 2014. Available from: https:/www.aiaee.org/attachments/ article/906/012.pdf.

11. Aliyu AS. Causes and Resolution of Conflict between Cattle Herders and Crop Farmers in Katsina State. M.Sc., Dissertation by the School of Postgraduate Studies, Ahmadu Bello University, Zaria; 2015. p. 1-74.

12. Tenuche MS, Ifatimehin OO. Resource conflict among farmers and Fulani herdsmen: Implications for resource sustainability. Afr J Pol Sci 2009;3:360-4.

13. Okoli M, Atelhe EN. Agricultural extension: Good intentions and hard realities. World Bank Res Obs 2014;19:112-23.

14. Aliyu AS. Causes and Resolution of Conflict between Cattle Herders and Crop Farmers in Katsina State. M.Sc., Dissertation School of Postgraduate Studies, Ahmadu Bello University, Zaria; 2015. p. 1-74.

15. Abbass AA. Farmers' perception and adoption of new agricultura technology: Evidence from analysis in Burkina Faso and Guinea, West Africa. J Agric Econ 2014;13:1-9. 